\title{
Effects of source/sink manipulation on grain zinc accumulation by winter wheat genotypes
}

\author{
Haiyong Xia ${ }^{1^{*}}$, Yanfang Xue ${ }^{2}$, Weilin Kong ${ }^{1}$, Yanyan Tang ${ }^{3}$, Jin $\mathrm{Li}^{3}$, and Dong $\mathrm{Li}^{3}$ \\ ${ }^{1}$ Crop Research Institute, Shandong Academy of Agricultural Sciences, Shandong Jinan 250100, PR China. \\ *Corresponding author (drhaiyongxia@gmail.com). \\ ${ }^{2}$ Maize Research Institute, Shandong Academy of Agricultural Sciences, Shandong Jinan 250100, PR China. \\ ${ }^{3}$ College of Life Sciences and Technology, Henan Institute of Science and Technology, Henan Xinxiang 453000, PR China.
}

Received: 9 October 2017; Accepted: 6 January 2018; doi:10.4067/S0718-58392018000100117

\begin{abstract}
Agronomy practices aimed at wheat (Triticum aestivum L.) grain Zn biofortification are important to alleviate $\mathrm{Zn}$ deficiency in humans, especially for those resource-poor people owing to subsistence on diets dominated by cereal-based foods with low concentrations and bioavailability of $\mathrm{Zn}$. To promote understanding of source-sink flow processes affecting biofortification of wheat with $\mathrm{Zn}$, effects of different source/sink manipulations on grain $\mathrm{Zn}$ accumulation by wheat were examined in pot and field at two locations. Treatments included foliar applications of deionized water, sucrose, $\mathrm{ZnSO}_{4}$, sucrose $+\mathrm{Zn}$, defoliation, spike shading or partial removal of spikes. Results showed sucrose $+\mathrm{Zn}$ significantly increased grain $\mathrm{Zn}$ concentration more than $\mathrm{Zn}$ alone. Grain $\mathrm{Zn}$ concentration with sucrose $+\mathrm{Zn}$ averaged $66 \mathrm{mg} \mathrm{kg}^{-1}$ for 'Kenong 9204' and $59 \mathrm{mg} \mathrm{kg}^{-1}$ for 'Liangxing 99' in pot, and ranged from 42 to $58 \mathrm{mg} \mathrm{kg}^{-1}$ for 'Liangxing 99', 'Jinan 17', 'Jimai 20', 'Jimai 22', and 'Luyuan 502' under field, approaching the field-grown target $60 \mathrm{mg} \mathrm{kg}^{-1}$ proposed by World Health Organization. Molar ratios of phytic acid/Zn and phytic acid $\times \mathrm{Ca} / \mathrm{Zn}$ of 'Jinan 17 ', 'Jimai 20 ' or 'Luyuan 502' with sucrose $+\mathrm{Zn}$ were reduced to be $<15$ and $<$ 200 , respectively, suggesting higher Zn bioavailability. Defoliation or spike shading decreased grain weight, $\mathrm{Zn}$ concentration and content. It is concluded that grain $\mathrm{Zn}$ accumulation of wheat can be affected by the sourcesink relationship of $\mathrm{Zn}$ and/or carbohydrate, and the foliar spray 'sucrose $+\mathrm{Zn}$ ' is recommended for increasing concentration and bioavailability of $\mathrm{Zn}$ in wheat grains.
\end{abstract}

Key words: Biofortification, carbohydrate, cereals, micronutrient, remobilization, Triticum aestivum.

\section{INTRODUCTION}

Wheat (Triticum aestivum L.) grains contain inherently too low $\mathrm{Zn}$ to meet daily human requirement, particularly when wheat crops are grown on Zn-deficient soils (Cakmak, 2008). In addition, wheat is rich in anti-nutritional compounds such as phytic acid and phenolic compounds that reduce biological availability of $\mathrm{Zn}$ in the human digestive tract (Cakmak et al., 2010b). It is therefore of great interest to increase Zn concentrations as well as bioavailability in wheat grains for human health benefits.

The movement of nutrients into grains is affected by the source-sink relationship at the grain-filling stage. Kutman et al. (2012) found that $\mathrm{Zn}$ remobilization rather than root uptake is critical for $\mathrm{Zn}$ accumulation in wheat grains when $\mathrm{Zn}$ availability in soil is restricted at the grain-filling stage. Foliar $\mathrm{Zn}$ application is much more effective than soil $\mathrm{Zn}$ application in $\mathrm{Zn}$ enrichment of wheat grains (Wang et al., 2012; Zhang et al., 2012b). The concentrations of $\mathrm{Zn}$ in wheat grains were positively correlated with foliar Zn rates (Zhang et al., 2012b). All these results suggested that $\mathrm{Zn}$ translocation to grains or grain sink strength is not a limiting factor and the grain $\mathrm{Zn}$ concentration is 
most probably limited by source supply (Zhang et al., 2012b). However, increasing Zn concentration in the culture solution from 10 to $100 \mu \mathrm{mol} \mathrm{L}-1$ failed to result in a 10 -fold increase in the wheat grain Zn concentration, perhaps as a result of saturating the membrane transporters during phloem loading (Pearson et al., 1996b). Wang et al. (2011) further reported that two barriers of $\mathrm{Zn}$ transport into wheat grains existed: 1) between the stem tissue rachis and the grain, and 2) between the maternal and the filial tissues in the grain. Therefore, the extent of source/sink limitation of grain $\mathrm{Zn}$ concentration and regulatory mechanisms need further studies.

The carbohydrate status in plants can influence the $\mathrm{Zn}$ transport into the grain. Pearson et al. (1996b) observed that the depletion of sucrose in the cultured ears of wheat through maintaining them in the dark decreased the transport of $\mathrm{Zn}$ to the grain, perhaps as a result of a decrease in mass flow of carbohydrates within the phloem. Due to the limitation of the grain sink capacity, sucrose at high supply rates may be accumulated in the peduncle and chaff, resulting in stomatal closure, the abatement of transportation by the xylem, and finally a decreased accumulation of micronutrients (including Zn) in grains (Ma et al., 1996). Recent studies showed the grain Zn concentration significantly decreased with increasing sucrose supply to detached ears, due to a dilution effect resulting from the increase in grain weight (Zhang et al., 2012a; Liu et al., 2014). However, it is unknown whether exogenous sucrose supply (with/without $\mathrm{Zn}$ ) affects grain $\mathrm{Zn}$ accumulation of wheat grown in soil.

Dry weight accumulation of grains is determined by the source-sink relationship of crop photoassimilates (Zhang et al., 2012a). Ma et al. (1996) and Wang et al. (1997) investigated the source-sink limitation for wheat grain growth by partial spikelet removal and defoliation. In their experiments, partial spikelet removal reduced the grain number and total sink size, and increased the source-to-sink ratio. Defoliation after anthesis decreased carbohydrate supply, and subsequently decreased single-grain weight and grain number. However, these studies analyzed only the grain growth and DM accumulation but not the accumulation dynamics of nutrients.

This study aimed to examine the effects of source and sink manipulations on grain $\mathrm{Zn}$ accumulation of wheat (Triticum aestivum L.) cultivars under controlled-environment and field conditions. Here we reduced carbohydrate source through defoliation and spike shading or increased it by reducing spike numbers after anthesis. Effects of foliar applications of sucrose and $\mathrm{Zn}$ alone or in combination on $\mathrm{Zn}$ accumulation and bioavailability of wheat grains were also studied. Zinc bioavailability in grains was estimated using molar ratios of phytic acid to $\mathrm{Zn}$ and phytic acid $\times \mathrm{Ca} / \mathrm{Zn}$ (Morris and Ellis, 1982; Ellis et al., 1987; Ryan et al., 2008). The results from these experiments provide novel information for guiding agronomic practices to enhance $\mathrm{Zn}$ biofortification of wheat grains.

\section{MATERIALS AND METHODS}

\section{Glasshouse experiment ('Kenong 9204' and 'Liangxing 99')}

Two winter wheat cultivars (Triticum aestivum L., 'Kenong 9204' and 'Liangxing 99' classified as high-yielding cultivars and widely cultivated in northern China) were grown in ceramic pots containing $4.0 \mathrm{~kg}$ air-dried calcareous soil in a glasshouse from December 2009 to May 2010. The basic properties of the soil were as follows: $\mathrm{pH} 8.0$

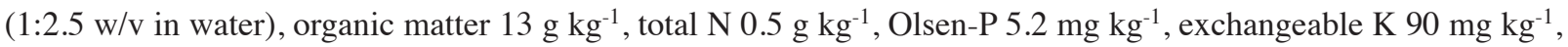
diethylenetriamine pentaacetic acid (DTPA)-extractable $\mathrm{Zn} 2.3 \mathrm{mg} \mathrm{kg}^{-1}$. Before sowing, the following nutrients were homogeneously incorporated into the soil (per kg dry soil): $150 \mathrm{mg} \mathrm{N}$ as urea (70\% applied as basal dose and $30 \%$ as the top-dressing at the jointing stage), $65.5 \mathrm{mg} \mathrm{P}$ in the form of calcium superphosphate containing $12 \%$ $\mathrm{P}_{2} \mathrm{O}_{5}, 124.5 \mathrm{mg} \mathrm{K}$ in the form of potassium sulfate for agriculture containing $50 \% \mathrm{~K}_{2} \mathrm{O}$ and $5 \mathrm{mg} \mathrm{Zn}$ in the form of $\mathrm{ZnSO}_{4} \cdot 7 \mathrm{H}_{2} \mathrm{O}$ with purity $\geq 99.5 \%$. Fifteen seeds per wheat cultivar were sown in each pot and seedlings were thinned to 10 after $9 \mathrm{~d}$.

The experiment was arranged in a complete randomized design. There were seven treatments in four replicates for 'Kenong 9204', and four foliar application treatments in three replicates for 'Liangxing 99' (Table 1). All solutions containing $0.01 \%(\mathrm{v} / \mathrm{v})$ Tween 20 as a surfactant were foliar-applied at $80 \mathrm{~mL}$ per pot after sunset. When spraying, the soil in pots was covered with plastic films to prevent possible contamination by solutions. The foliar applications were conducted four times at 1-wk intervals from $5 \mathrm{~d}$ after flowering. At maturity, all plants were harvested and grains were separated manually from straw. 
Table 1. Source/sink treatments on winter wheat grown under glasshouse or field conditions.

\begin{tabular}{|c|c|}
\hline Treatments & $\begin{array}{l}\text { Nutrient concentration of foliar spray or other treated } \\
\text { methods after wheat anthesis }\end{array}$ \\
\hline Control & Deionized water \\
\hline T2 Sucrose & $3.0 \%(\mathrm{w} / \mathrm{v})$ \\
\hline $\mathrm{ZnSO}_{4} \cdot 7 \mathrm{H}_{2} \mathrm{O}(\mathrm{Zn})$ & $0.3 \%(\mathrm{w} / \mathrm{v})(0.4 \%$ for the last experiment $)$ \\
\hline T4 Sucrose + Zn & $3.0 \%$ and $0.3 \%(\mathrm{w} / \mathrm{v})(0.4 \% \mathrm{Zn}$ for the last experiment $)$ \\
\hline Partial spike removal & Removing stunting spikes from tillers \\
\hline Spike shading & Covering all spikes with water-proof bags \\
\hline T7 Defoliation & Removing all leaf blades from wheat after anthesis \\
\hline
\end{tabular}

Field experiment ('Liangxing 99') at Quzhou experimental station during the 2009-2010 cropping season

A field experiment was conducted at Quzhou experimental station $\left(36.9^{\circ} \mathrm{N}, 115.0^{\circ} \mathrm{E}\right)$ in Hebei province of China by only one cropping season of winter wheat (2009-2010). The soil characteristics were calcareous alluvial soil typical of the North Plain of China, pH 8.3 (1:2.5 w/v in water) and $14 \mathrm{~g} \mathrm{~kg}^{-1}$ organic matter. The DTPA-extractable Zn was $3.2 \mathrm{mg} \mathrm{kg}^{-1}$ before sowing. The climatic conditions of the experiment have been previously reported by Zhang et al. (2013).

Wheat 'Liangxing 99' was planted in a complete randomized design with four replicates. The amount of $\mathrm{N}$ application is the commonly applied $300 \mathrm{~kg} \mathrm{~N} \mathrm{ha}^{-1}$ as urea. Other detailed information about fertilizer application and crop husbandry were previously described by Xue et al. (2014). The treatments (T1-T7) were same as those applied to 'Kenong 9204' in the glasshouse (Table 1). All solutions containing $0.01 \%$ (v/v) Tween 20 as a surfactant were applied at $600 \mathrm{~L} \mathrm{ha}^{-1}\left(60 \mathrm{~mL} \mathrm{~m}^{-2}\right)$ after sunset. The area of each replicate for treatments T1-T4 was $10 \mathrm{~m}^{2}$ and $1 \mathrm{~m}^{2}$ each for T5-T7. At maturity, plants from T1-T4 were harvested manually in a $2 \mathrm{~m}^{2}$ area. For T5-T7, all plants were harvested manually.

Field experiment ('Jinan 17', 'Jimai 20', 'Jimai 22' and 'Luyuan 502') at Yinmaquan experimental station during the 2014-2015 cropping season

Another field experiment was conducted during the 2014-2015 cropping season at Yinmaquan Experimental Station (36 $43^{\prime} \mathrm{N}, 117^{\circ} 5^{\prime} \mathrm{E}$; $48 \mathrm{~m}$ a.s.1.), Shandong Academy of Agricultural Sciences, China. The area is a typical continental and warm climate, with an annual mean temperature of $13.6{ }^{\circ} \mathrm{C}$ and a long-term mean annual rainfall of $625 \mathrm{~mm}$. The soil at the site was classified as sandy loam, with a pH of 7.8. The top $20 \mathrm{~cm}$ of the soil contained 19 $\mathrm{g} \mathrm{kg}^{-1}$ organic matter, $49 \mathrm{mg} \mathrm{kg}^{-1}$ water-hydrolysable $\mathrm{N}, 24 \mathrm{mg} \mathrm{kg}-1$ Olsen-P, $162 \mathrm{mg} \mathrm{kg}^{-1}$ exchangeable $\mathrm{K}$ and 1.5 $\mathrm{mg} \mathrm{kg}^{-1}$ DTPA-extractable $\mathrm{Zn}$. All the P fertilizer ( $52 \mathrm{~kg} \mathrm{Pha}^{-1}$, supplied as calcium superphosphate), $\mathrm{K}$ fertilizer (83 $\mathrm{kg} \mathrm{K} \mathrm{ha}^{-1}$, supplied as potassium sulfate), $\mathrm{Zn}$ fertilizer $\left(6.8 \mathrm{~kg} \mathrm{Zn} \mathrm{ha}^{-1}\right.$, supplied as $\left.\mathrm{ZnSO}_{4} \cdot 7 \mathrm{H}_{2} \mathrm{O}\right)$ and $113 \mathrm{~kg} \mathrm{~N}^{-1}$ (supplied as urea) were evenly broadcast and incorporated into the upper $20 \mathrm{~cm}$ of the soil prior to wheat sowing. The other half of the $\mathrm{N}$ was top-dressed as urea at the jointing stage.

The experiment was a split-plot design, and consisted of three foliar spray treatments (subplot) and four cultivars (main plot) in four replicates. Four winter wheat cultivars were 'Jinan 17', 'Jimai 20', 'Jimai 22' and 'Luyuan 502'. 'Jinan 17 ' is a high-quality strong gluten cultivar, suitable for making bread. 'Jimai 20' is suitable for making both bread and noodles. 'Jimai 22' is a high-yielding wheat cultivar and sown on the largest area in contemporary China. 'Luyuan 502' is also a high-yielding wheat cultivar, which is widely cultivated in northern China. The three foliar treatments were T1, T3 and T4 as shown in Table 1. Compared to the first field study, the concentration of $\mathrm{ZnSO}_{4}$. $7 \mathrm{H}_{2} \mathrm{O}$ in $\mathrm{T} 3$ and $\mathrm{T} 4$ was increased from $0.3 \%$ to $0.4 \%(\mathrm{w} / \mathrm{v})$ in this experiment. All foliar solutions contained $0.01 \%$ $(\mathrm{v} / \mathrm{v})$ Tween 20 as a surfactant and the application rate was increased from 600 to $900 \mathrm{~L} \mathrm{ha}^{-1}$ (equal to $90 \mathrm{~mL} \mathrm{~m}^{-2}$ ) after sunset. The area of the main plot was $80 \mathrm{~m}^{2}$, and of subplot $10 \mathrm{~m}^{2}$ each. At maturity, wheat plants from T1, T3 and T4 were harvested manually in a $1 \mathrm{~m}^{2}$ area in the center of each split-plot.

\section{Nutrient analysis}

After being washed with deionized water, grain samples were dried at $60-65^{\circ} \mathrm{C}$ for $72 \mathrm{~h}$. The dried samples were ground with a stainless steel grinder (RT-02B, Chinese Taipei) and digested with $\mathrm{HNO}_{3}-\mathrm{H}_{2} \mathrm{O}_{2}$ in a closed microwave 
digester (CEM, Matthews, North Carolina, USA). The concentrations of nutrients in the digests were determined by inductively coupled plasma atomic emission spectroscopy (ICP-AES, OPTIMA 3300 DV, Perkin-Elmer, Waltham, Massachusetts, USA). A reference grain sample IPE556 from Wageningen University was included in each batch to ensure analytical quality. Phytate P concentration in the Yinmaquan field experiment was analyzed according to the method of Haug and Lantzsch (1983). Phytate P was converted to phytic acid (PA) by dividing by 0.282 to calculate molar ratios of $\mathrm{PA} / \mathrm{Zn}$ and $\mathrm{PA} \times \mathrm{Ca} / \mathrm{Zn}$.

\section{Statistical analysis}

Data from the single-factor completely randomized design and split-plot design experiments were subjected to ANOVA using SAS software (SAS 8.0, SAS Institute, Cary, North Carolina, USA) and mean values were compared by the least significant difference (LSD) at the $5 \%$ level.

\section{RESULTS}

\section{Yield traits, grain $\mathrm{Zn}$ concentrations and contents of wheat from pot experiments}

Compared with the control (T1), only defoliation (T7) significantly decreased grain yield and biomass while other treatments (T2-T6) did not (Table 2). Thousand kernel weight (TKW) varied from 28.9 to $49.4 \mathrm{~g}$. Spike shading (T6) significantly decreased the TKW compared with T1, while T7 led to a further decrease compared to T6. Harvest index (HI) varied from $47.3 \%$ to $54.6 \%$, with $\mathrm{T} 7$ treatment also being the lowest. Compared with partial spike removal, spike shading and defoliation decreased grain yield, biomass and TKW gradually. In addition, defoliation decreased kernels per spike and HI (Table 2).

For 'Kenong 9204', foliar spray of Zn increased grain Zn concentration by $135 \%$ and $211 \%$ for T3 and T4, respectively, compared with the $\mathrm{T} 1$ treatment while other treatments did not (Table 3). Grain $\mathrm{Zn}$ concentration increased from 21.1 to $49.6 \mathrm{mg} \mathrm{kg}^{-1}$ by Zn-only treatment, and further increased to $65.7 \mathrm{mg} \mathrm{kg}^{-1}$ by the sucrose $+\mathrm{Zn}$ spray. Grain Zn contents were $123 \%$ and $217 \%$ higher in T3 and T4, respectively, but $44 \%$ and $57 \%$ lower in T6 and T7, respectively, and not affected by T2 and T5 significantly, as compared with T1. For 'Liangxing 99', both grain Zn concentration and content were in the order of $\mathrm{T} 1<\mathrm{T} 2<\mathrm{T} 3<\mathrm{T} 4$ (Table 3). The foliar spray of sucrose $+\mathrm{Zn}$ (T4) led to the highest $\mathrm{Zn}$ concentration $\left(59.0 \mathrm{mg} \mathrm{kg}^{-1}\right)$, and increased grain $\mathrm{Zn}$ content by $345 \%$, compared with $\mathrm{T} 1$.

Yield traits, grain Zn concentrations and contents of wheat 'Liangxing 99' under field conditions at Quzhou Compared with the control (T1), foliar treatments (T2-T4) had nonsignificant effects on grain yield and TKW (Table 4). While $\mathrm{T} 5$ significantly increased TKW, T6 and $\mathrm{T} 7$ significantly decreased $\mathrm{TKW}$. The grain Zn concentration was increased from $35.0 \mathrm{mg} \mathrm{kg}^{-1}$ in the control to $38.7 \mathrm{mg} \mathrm{kg}^{-1}$ by the foliar spray of $\mathrm{Zn}$ alone, and increased further from 38.7 to $42.2 \mathrm{mg} \mathrm{kg}^{-1}$ by spray of sucrose $+\mathrm{Zn}$ combined solution. Compared with T1, other treatments (T2, T5, T6

Table 2. Effects of different source/sink treatments on yield parameters of two wheat cultivars in the pot experiment.

\begin{tabular}{|c|c|c|c|c|c|c|c|}
\hline Cultivars & & Treatments & Grain yield & Biomass & Kernels & TKW & $\mathrm{HI}$ \\
\hline & & & $\mathrm{g}$ pot $^{-1}$ & $\mathrm{~g} \mathrm{pot}^{-1}$ & nr spike ${ }^{-1}$ & $\mathrm{~g}$ & $\%$ \\
\hline \multirow[t]{7}{*}{ Kenong 9204} & $\mathrm{~T} 1$ & Deionized water & $15.9 \mathrm{ab}$ & $29.6 \mathrm{ab}$ & $35.0 \mathrm{abc}$ & $45.5 \mathrm{ab}$ & $53.7 \mathrm{a}$ \\
\hline & $\mathrm{T} 2$ & Sucrose & $15.8 \mathrm{ab}$ & $29.9 \mathrm{ab}$ & $31.9 \mathrm{bc}$ & $49.4 \mathrm{a}$ & $52.3 \mathrm{a}$ \\
\hline & $\mathrm{T} 3$ & $\mathrm{ZnSO}_{4} \cdot 7 \mathrm{H}_{2} \mathrm{O}(\mathrm{Zn})$ & $15.5 \mathrm{ab}$ & $29.1 \mathrm{ab}$ & $36.7 \mathrm{ab}$ & $42.4 \mathrm{bc}$ & $53.4 \mathrm{a}$ \\
\hline & $\mathrm{T} 4$ & Sucrose $+\mathrm{Zn}$ & $16.6 \mathrm{a}$ & $31.5 \mathrm{a}$ & $35.3 \mathrm{abc}$ & $47.2 \mathrm{ab}$ & $52.8 \mathrm{a}$ \\
\hline & $\mathrm{T} 5$ & Partial spike removal & $18.3 \mathrm{a}$ & $33.6 \mathrm{a}$ & $37.3 \mathrm{a}$ & $49.2 \mathrm{ab}$ & $54.6 \mathrm{a}$ \\
\hline & T6 & Spike shading & $13.8 \mathrm{~b}$ & $26.5 b$ & $38.5 \mathrm{a}$ & $36.1 \mathrm{c}$ & $52.0 \mathrm{a}$ \\
\hline & $\mathrm{T} 7$ & Defoliation & $8.8 \mathrm{c}$ & $18.7 \mathrm{c}$ & $31.2 \mathrm{c}$ & $28.9 \mathrm{~d}$ & $47.3 b$ \\
\hline \multirow[t]{4}{*}{ Liangxing 99} & $\mathrm{~T} 1$ & Deionized water & $15.0 \mathrm{ab}$ & $28.8 \mathrm{ab}$ & $37.0 \mathrm{a}$ & $41.1 \mathrm{a}$ & $52.0 \mathrm{ab}$ \\
\hline & $\mathrm{T} 2$ & Sucrose & $14.3 \mathrm{~b}$ & $27.4 \mathrm{~b}$ & $37.0 \mathrm{a}$ & $38.8 \mathrm{a}$ & $52.2 \mathrm{ab}$ \\
\hline & $\mathrm{T} 3$ & $\mathrm{ZnSO}_{4} \cdot 7 \mathrm{H}_{2} \mathrm{O}(\mathrm{Zn})$ & $16.9 \mathrm{a}$ & $31.4 \mathrm{a}$ & $41.0 \mathrm{a}$ & $41.0 \mathrm{a}$ & $53.9 \mathrm{a}$ \\
\hline & $\mathrm{T} 4$ & Sucrose $+\mathrm{Zn}$ & $16.1 \mathrm{ab}$ & $31.3 \mathrm{ab}$ & $42.0 \mathrm{a}$ & $38.0 \mathrm{a}$ & $51.3 b$ \\
\hline
\end{tabular}

TKW: Thousand kernels weight; HI: harvest index.

Values are means of four and three replicates for 'Kenong 9204' and 'Liangxing 99', respectively.

Values in the same column per cultivar followed by different lower-case letters are significantly different among the treatments according to Fisher's Protected LSD test $(P \leq 0.05)$. 
Table 3. Effects of different source/sink treatments on grain $\mathrm{Zn}$ concentration and content of two wheat cultivars in the pot experiment.

\begin{tabular}{|c|c|c|c|c|}
\hline Cultivars & & Treatments & Zn concentration & $\mathrm{Zn}$ content \\
\hline & & & $\mathrm{mg} \mathrm{kg}^{-1}$ & $\mu \mathrm{g} \operatorname{pot}^{-1}$ \\
\hline \multirow[t]{7}{*}{ Kenong 9204} & $\mathrm{~T} 1$ & Deionized water & $21.1 \mathrm{c}$ & $345 c$ \\
\hline & $\mathrm{T} 2$ & Sucrose & $16.3 \mathrm{c}$ & $255 \mathrm{~cd}$ \\
\hline & $\mathrm{T} 3$ & $\mathrm{ZnSO}_{4} \cdot 7 \mathrm{H}_{2} \mathrm{O}(\mathrm{Zn})$ & $49.6 b$ & $770 \mathrm{~b}$ \\
\hline & $\mathrm{T} 4$ & Sucrose $+\mathrm{Zn}$ & $65.7 \mathrm{a}$ & $1092 \mathrm{a}$ \\
\hline & T5 & Partial spike removal & $20.4 \mathrm{c}$ & $373 c$ \\
\hline & T6 & Spike shading & $14.0 \mathrm{c}$ & $193 d$ \\
\hline & $\mathrm{T} 7$ & Defoliation & $16.9 \mathrm{c}$ & $147 d$ \\
\hline \multirow[t]{4}{*}{ Liangxing 99} & $\mathrm{~T} 1$ & Deionized water & $14.2 \mathrm{~d}$ & $213 c$ \\
\hline & $\mathrm{T} 2$ & Sucrose & $24.2 \mathrm{c}$ & $347 \mathrm{c}$ \\
\hline & $\mathrm{T} 3$ & $\mathrm{ZnSO}_{4} \cdot 7 \mathrm{H}_{2} \mathrm{O}(\mathrm{Zn})$ & $38.5 b$ & $649 b$ \\
\hline & $\mathrm{T} 4$ & Sucrose $+\mathrm{Zn}$ & $59.0 \mathrm{a}$ & $948 \mathrm{a}$ \\
\hline
\end{tabular}

Values are means of four and three replicates for 'Kenong 9204' and 'Liangxing 99', respectively.

Values in the same column per cultivar followed by different lower-case letters are significantly different among different treatments according to Fisher's Protected LSD test $(P \leq 0.05)$.

Table 4. Effects of different source/sink manipulations on grain yield traits, grain $\mathrm{Zn}$ concentration and content of wheat 'Liangxing 99' in the field experiment at Quzhou.

\begin{tabular}{lcccc}
\hline Treatments & Yield & TKW & Zn concentration & Zn content \\
\hline & $\mathrm{t} \mathrm{ha}^{-1}$ & $\mathrm{~g}$ & $\mathrm{mg} \mathrm{kg}^{-1}$ & $\mathrm{~g} \mathrm{ha}^{-1}$ \\
T1 Deionized water & $6.5 \mathrm{a}$ & $37.6 \mathrm{~b}$ & $35.0 \mathrm{bc}$ & $228.0 \mathrm{bc}$ \\
T2 Sucrose & $6.2 \mathrm{a}$ & $38.0 \mathrm{~b}$ & $30.8 \mathrm{c}$ & $191.1 \mathrm{c}$ \\
$\mathrm{T}^{2} \mathrm{ZnSO}_{4} \cdot 7 \mathrm{H}_{2} \mathrm{O}(\mathrm{Zn})$ & $6.4 \mathrm{a}$ & $35.4 \mathrm{bc}$ & $38.7 \mathrm{ab}$ & $246.7 \mathrm{ab}$ \\
T4 Sucrose $+\mathrm{Zn}$ & $6.4 \mathrm{a}$ & $36.8 \mathrm{bc}$ & $42.2 \mathrm{a}$ & $271.6 \mathrm{a}$ \\
T5 Partial spike removal & - & $45.5 \mathrm{a}$ & $34.9 \mathrm{bc}$ & - \\
T6 Spike shading & - & $29.5 \mathrm{~d}$ & $33.9 \mathrm{bc}$ & - \\
T7 Defoliation & - & $30.6 \mathrm{~d}$ & $33.0 \mathrm{bc}$ & - \\
\hline
\end{tabular}

TKW: Thousand kernels weight.

Values in the same column followed by different lower-case letters are significantly different among various source/sink treatments according to Fisher's Protected LSD test $(P \leq 0.05)$.

and T7) had nonsignificant effects on grain Zn concentrations. In addition, compared with T1, Zn-only treatment and sucrose $+\mathrm{Zn}$ increased the grain $\mathrm{Zn}$ content (Table 4).

Yield, grain $\mathrm{Zn}$ traits, and molar ratios of grain $\mathrm{PA} / \mathrm{Zn}$ and $\mathrm{PA} \times \mathrm{Ca} / \mathrm{Zn}$ of 'Jinan 17', 'Jimai 20', 'Jimai 22' and 'Luyuan 502' under field conditions at Yinmaquan

Wheat cultivars differed in TKW, grain $\mathrm{Zn}$ concentrations and contents, and molar ratios of PA/Zn and PA $\times \mathrm{Ca} /$ Zn (Table 5). On average, the high-yielding 'Jimai 22' and 'Luyuan 502' had higher TKW, grain Zn contents, and molar ratios of PA/Zn and PA $\times \mathrm{Ca} / \mathrm{Zn}$ than 'Jimai 20' and 'Jinan 17'. 'Jinan 17', as a high-quality strong gluten wheat cultivar, had the lowest TKW and molar ratios of PA/Zn and PA $\times \mathrm{Ca} / \mathrm{Zn}$. 'Jimai 20' had significantly lower grain $\mathrm{Zn}$ concentration and content than other cultivars. On average, the grain $\mathrm{Zn}$ concentration was significantly increased from the initial 40.9 to $51.6 \mathrm{mg} \mathrm{kg}^{-1}$ by Zn-only treatment and significantly increased further from 51.6 to $56.2 \mathrm{mg} \mathrm{kg}^{-1}$ by sucrose $+\mathrm{Zn}$. Similar results were found in grain $\mathrm{Zn}$ contents. In contrast, T3 and T4 decreased molar ratios of PA/Zn by $20.1 \%$ and $29.6 \%$, respectively, and decreased molar ratios of $\mathrm{PA} \times \mathrm{Ca} / \mathrm{Zn}$ by $21.8 \%$ and $30.1 \%$, respectively.

\section{Pearson correlations among grain $\mathrm{Zn}$ concentration and other related parameters}

Grain $\mathrm{Zn}$ concentration positively correlated with grain $\mathrm{Zn}$ content (Tables 6 and 7). There was significant and positive correlation between grain $\mathrm{Zn}$ concentration/content and TKW under field conditions (Table 7), however, 
this phenomenon was not observed in the pot experiment (Table 6). Grain Zn concentration negatively correlated with $\mathrm{PA} / \mathrm{Zn}$ and $\mathrm{PA} \times \mathrm{Ca} / \mathrm{Zn}$ and $\mathrm{Zn}$ content negatively correlated with $\mathrm{PA} / \mathrm{Zn}$, indicating the higher grain $\mathrm{Zn}$ concentration represented corresponding higher grain $\mathrm{Zn}$ bioavailability (Table 7). Positive correlations between grain yield and TKW or grain Zn content were found in both pot and field experiments (Tables 6 and 7). TKW positively correlated with $\mathrm{PA} / \mathrm{Zn}$ and $\mathrm{PA} \times \mathrm{Ca} / \mathrm{Zn}$, respectively (Table 7).

Table 5. Effects of different foliar applications on grain yield, thousand kernel weight (TKW), grain Zn concentration and content, and molar ratios of grain phytic acid $(\mathrm{PA}) / \mathrm{Zn}$ and $\mathrm{PA} \times \mathrm{Ca} / \mathrm{Zn}$ of four different winter wheat cultivars in the field experiment at Yinmaquan.

\begin{tabular}{|c|c|c|c|c|c|c|c|c|c|}
\hline \multirow[b]{2}{*}{ Parameters } & & \multirow[b]{2}{*}{ Treatments } & \multicolumn{5}{|c|}{ Winter wheat cultivars } & & \\
\hline & & & Jinan 17 & Jimai 20 & Jimai 22 & Luyuan 502 & Mean & \multicolumn{2}{|c|}{$P$} \\
\hline \multirow[t]{4}{*}{ Yield, $\mathrm{t} \mathrm{ha}^{-1}$} & $\mathrm{~T} 1$ & Deionized water & $7.4 \mathrm{a}$ & $7.4 \mathrm{a}$ & $7.3 \mathrm{a}$ & $7.5 \mathrm{a}$ & $7.4 \mathrm{~A}$ & $\mathrm{C}$ & 0.6279 \\
\hline & $\mathrm{T} 3$ & $\mathrm{ZnSO}_{4} \cdot 7 \mathrm{H}_{2} \mathrm{O}(\mathrm{Zn})$ & $6.8 \mathrm{a}$ & $7.0 \mathrm{a}$ & $7.7 \mathrm{a}$ & $6.9 \mathrm{a}$ & $7.1 \mathrm{~A}$ & $\mathrm{~T}$ & 0.5284 \\
\hline & $\mathrm{T} 4$ & Sucrose $+\mathrm{Zn}$ & $7.1 \mathrm{a}$ & $7.0 \mathrm{a}$ & $7.3 \mathrm{a}$ & $7.3 \mathrm{a}$ & $7.2 \mathrm{~A}$ & $\mathrm{C} \times \mathrm{T}$ & 0.7625 \\
\hline & & Mean & $7.1 \mathrm{~A}$ & $7.1 \mathrm{~A}$ & $7.5 \mathrm{~A}$ & $7.2 \mathrm{~A}$ & & & \\
\hline \multirow[t]{4}{*}{ TKW, g } & $\mathrm{T} 1$ & Deionized water & $40.9 \mathrm{a}$ & $43.1 \mathrm{ab}$ & $46.8 \mathrm{a}$ & $49.5 \mathrm{a}$ & $45.1 \mathrm{~A}$ & $\mathrm{C}$ & $<0.0001$ \\
\hline & $\mathrm{T} 3$ & $\mathrm{ZnSO}_{4} \cdot 7 \mathrm{H}_{2} \mathrm{O}(\mathrm{Zn})$ & $40.2 \mathrm{a}$ & $44.2 \mathrm{a}$ & $45.2 \mathrm{a}$ & $48.5 \mathrm{a}$ & $44.5 \mathrm{~A}$ & $\mathrm{~T}$ & 0.6803 \\
\hline & $\mathrm{T} 4$ & Sucrose $+\mathrm{Zn}$ & $44.2 \mathrm{a}$ & $42.6 b$ & $45.9 \mathrm{a}$ & $48.4 \mathrm{a}$ & $45.3 \mathrm{~A}$ & $\mathrm{C} \times \mathrm{T}$ & 0.3823 \\
\hline & & Mean & $41.8 \mathrm{C}$ & 43.3BC & 46.0B & 48.8A & & & \\
\hline \multirow{4}{*}{$\begin{array}{l}\text { Grain } \mathrm{Zn} \text { concentrations, } \\
\mathrm{mg} \mathrm{kg}^{-1}\end{array}$} & $\mathrm{~T} 1$ & Deionized water & $40.0 \mathrm{~b}$ & $34.9 \mathrm{~b}$ & $42.9 \mathrm{c}$ & $45.8 \mathrm{c}$ & $40.9 \mathrm{C}$ & $\mathrm{C}$ & $<0.0001$ \\
\hline & $\mathrm{T} 3$ & $\mathrm{ZnSO}_{4} \cdot 7 \mathrm{H}_{2} \mathrm{O}(\mathrm{Zn})$ & $51.8 \mathrm{a}$ & $48.5 \mathrm{a}$ & $51.7 \mathrm{~b}$ & $54.6 \mathrm{~b}$ & $51.6 \mathrm{~B}$ & $\mathrm{~T}$ & $<0.0001$ \\
\hline & $\mathrm{T} 4$ & Sucrose $+\mathrm{Zn}$ & $59.7 \mathrm{a}$ & $50.5 \mathrm{a}$ & $56.3 \mathrm{a}$ & $58.4 \mathrm{a}$ & $56.2 \mathrm{~A}$ & $\mathrm{C} \times \mathrm{T}$ & 0.3904 \\
\hline & & Mean & $50.5 A$ & 44.6B & $50.3 \mathrm{~A}$ & 52.9A & & & \\
\hline \multirow[t]{4}{*}{ Grain $\mathrm{Zn}$ contents, $\mathrm{g}^{-1}$} & $\mathrm{~T} 1$ & Deionized water & $296 b$ & $257 b$ & $312 b$ & $342 b$ & $302 \mathrm{C}$ & $\mathrm{C}$ & 0.0043 \\
\hline & $\mathrm{T} 3$ & $\mathrm{ZnSO}_{4} \cdot 7 \mathrm{H}_{2} \mathrm{O}(\mathrm{Zn})$ & $353 \mathrm{ab}$ & $340 \mathrm{a}$ & $401 \mathrm{a}$ & $376 a b$ & $368 \mathrm{~B}$ & $\mathrm{~T}$ & $<0.0001$ \\
\hline & $\mathrm{T} 4$ & Sucrose $+\mathrm{Zn}$ & $427 \mathrm{a}$ & $351 \mathrm{a}$ & $412 \mathrm{a}$ & $424 \mathrm{a}$ & $404 \mathrm{~A}$ & $\mathrm{C} \times \mathrm{T}$ & 0.6160 \\
\hline & & Mean & 359A & 316B & 375A & $381 \mathrm{~A}$ & & & \\
\hline \multirow[t]{4}{*}{$\mathrm{PA} / \mathrm{Zn}$} & $\mathrm{T} 1$ & Deionized water & $16.7 \mathrm{a}$ & $18.1 \mathrm{a}$ & $24.1 \mathrm{a}$ & $20.8 \mathrm{a}$ & $19.9 \mathrm{~A}$ & $\mathrm{C}$ & 0.0016 \\
\hline & $\mathrm{T} 3$ & $\mathrm{ZnSO}_{4} \cdot 7 \mathrm{H}_{2} \mathrm{O}(\mathrm{Zn})$ & $15.0 \mathrm{a}$ & $15.2 b$ & $18.2 b$ & $15.3 b$ & 15.9B & $\mathrm{T}$ & $<0.0001$ \\
\hline & $\mathrm{T} 4$ & Sucrose $+\mathrm{Zn}$ & $12.3 \mathrm{a}$ & $13.3 b$ & $16.6 \mathrm{~b}$ & $13.6 \mathrm{~b}$ & $14.0 \mathrm{C}$ & $\mathrm{C} \times \mathrm{T}$ & 0.5519 \\
\hline & & Mean & 14.7B & 15.5B & 19.7A & $16.5 \mathrm{~B}$ & & & \\
\hline \multirow[t]{4}{*}{$\mathrm{PA} \times \mathrm{Ca} / \mathrm{Zn}, \mathrm{mmol} \mathrm{kg}{ }^{-1}$} & $\mathrm{~T} 1$ & Deionized water & $157 \mathrm{a}$ & $200 \mathrm{a}$ & $310 \mathrm{a}$ & $248 \mathrm{a}$ & $229 \mathrm{~A}$ & $\mathrm{C}$ & 0.0002 \\
\hline & $\mathrm{T} 3$ & $\mathrm{ZnSO}_{4} \cdot 7 \mathrm{H}_{2} \mathrm{O}(\mathrm{Zn})$ & $146 \mathrm{a}$ & $171 b$ & $236 b$ & $164 b$ & 179B & $\mathrm{T}$ & $<0.0001$ \\
\hline & $\mathrm{T} 4$ & Sucrose $+\mathrm{Zn}$ & $124 \mathrm{a}$ & $153 b$ & $205 b$ & $158 b$ & $160 \mathrm{~B}$ & $\mathrm{C} \times \mathrm{T}$ & 0.2980 \\
\hline & & Mean & $142 C$ & 175B & $250 \mathrm{~A}$ & 190B & & & \\
\hline
\end{tabular}

Values in the same column per parameter followed by different lower-case letters are significantly different among various foliar treatments according to Fisher's Protected LSD test $(P \leq 0.05)$.

Values of each parameter followed by different capital letters are significantly different among different wheat cultivars (horizontal comparison) or among various foliar treatments (vertical comparison) according to Fisher's Protected LSD test $(P \leq 0.05)$.

Table 6. Pearson correlation coefficients among grain $\mathrm{Zn}$ concentration and other related parameters across all cultivars ('Kenong 9204' and 'Liangxing 99') in the pot experiment.

\begin{tabular}{|c|c|c|c|c|c|c|c|}
\hline Parameters & $\begin{array}{c}\mathrm{Zn} \\
\text { concentration }\end{array}$ & $\begin{array}{l}\text { Grain } \\
\text { yield }\end{array}$ & $\begin{array}{l}\text { Biomass } \\
\text { yield }\end{array}$ & TKW & $\begin{array}{l}\text { Kernels } \\
\text { per spike }\end{array}$ & $\mathrm{HI}$ & $\mathrm{Zn}$ content \\
\hline Zn concentration & - & 0.307 & 0.344 & 0.176 & 0.245 & 0.161 & $0.985^{* * * *}$ \\
\hline Grain yield & - & - & $0.987^{* * *}$ & $0.779^{* * * *}$ & $0.499^{* *}$ & $0.840^{* * * *}$ & $0.453^{*}$ \\
\hline Biomass yield & - & - & - & $0.750^{* * * *}$ & $0.533^{* *}$ & $0.747^{* * * *}$ & $0.486^{*}$ \\
\hline TKW & - & - & - & - & -0.146 & $0.716^{* * *}$ & 0.287 \\
\hline Kernels per spike & - & - & - & - & - & 0.295 & 0.320 \\
\hline Harvest index (HI) & - & - & - & - & - & - & 0.287 \\
\hline Zncontent & - & - & - & - & - & - & - \\
\hline
\end{tabular}

TKW: Thousand kernels weight.

${ }^{*},{ }^{*},{ }^{* * *}$ Significant correlations at the $0.05,0.01$, and 0.001 probability levels, respectively. 
Table 7. Pearson correlation coefficients among grain $\mathrm{Zn}$ concentration and other related parameters across all cultivars under two field conditions.

\begin{tabular}{|c|c|c|c|c|c|c|}
\hline Parameters & $\begin{array}{c}\mathrm{Zn} \\
\text { concentration }\end{array}$ & $\begin{array}{l}\text { Grain } \\
\text { yield }\end{array}$ & TKW & $\begin{array}{c}\mathrm{Zn} \\
\text { content }\end{array}$ & $\mathrm{PA} / \mathrm{Zn}$ & $\mathrm{PA} \times \mathrm{Ca} / \mathrm{Zn}$ \\
\hline Zn concentration & - & 0.205 & $0.558^{* * * *}$ & $0.898^{* * *}$ & $-0.456^{* * *}$ & $-0.306^{*}$ \\
\hline Grain yield & - & - & $0.427^{* * *}$ & $0.609^{* * *}$ & 0.122 & 0.102 \\
\hline $\mathrm{TKW}$ & - & - & - & $0.590^{* * *}$ & $0.308^{*}$ & $0.377^{* *}$ \\
\hline Zn content & - & - & - & - & $-0.338^{*}$ & -0.215 \\
\hline Phytic acid (PA)/Zn & - & - & - & - & - & $0.946^{* * *}$ \\
\hline $\mathrm{PA} \times \mathrm{Ca} / \mathrm{Zn}$ & - & - & - & - & - & - \\
\hline
\end{tabular}

TKW: Thousand kernels weight.

${ }^{*},{ }^{* *},{ }^{* * *}$ Significant correlations at the $0.05,0.01$, and 0.001 probability levels, respectively.

\section{DISCUSSION}

This study showed that partial spike removal enlarged the grain sink, resulting in higher grain yield, biomass and TKW, without affecting the grain Zn concentration (Tables 2-4). TKW positively correlated with grain Zn concentration and content under field conditions but not in the pot experiment (Tables 6 and 7), which need to be further studied in the future. The reduction in photosynthetic source by shading spikes and especially by defoliation substantially decreased grain yield, biomass, grain size, and harvest index of wheat. Similar results were reported (Zhang et al., 2012a; Liu et al., 2014). Zhang et al. (2012a) showed that reducing source (through defoliation and spike shading) or sink (through removal of 50\% spikelets) increased wheat grain $\mathrm{Zn}$ concentrations under field conditions. However, there was a trend that spike-shading and defoliation decreased wheat grain $\mathrm{Zn}$ concentrations, compared with control, under both controlled environment and field conditions (Tables 3 and 4). The grain $\mathrm{Zn}$ content of 'Kenong 9204' was reduced due to reduced grain weights in defoliation and spike shading. Similar results were found by Zhang et al. (2012a) that defoliation, spike shading and removal of 50\% spikelets decreased grain Zn contents. The present study suggests that reducing photosynthetic source by defoliation and spike-shading changes source-sink relationships, decreases wheat grain weights, and further reduces grain $\mathrm{Zn}$ accumulation.

It has been reported that increased sucrose supply within the optimal level substantially enhanced grain yield and single grain weight of rice and wheat under detached-ear culture (Sasaki et al., 2005; Zhang et al., 2012a; Liu et al., 2014). Sasaki et al. (2005) speculated that the increase was due to the improved activities of enzymes involved in starch synthesis. However, in both pot and field experiments of our study, sucrose spraying with or without $\mathrm{Zn}$ had nonsignificant effects on grain yield components and harvest index (Tables 2, 4 and 5), indicating that DM accumulation in grains is less affected by external carbohydrate supply. It was shown that ${ }^{65} \mathrm{Zn}$ was not transported within the grain in the same way as ${ }^{14} \mathrm{C}$-sucrose (Pearson et al., 1996a). Our study showed the foliar spray of only sucrose had nonsignificant effect on grain $\mathrm{Zn}$ contents in wheat (Tables 3 and 4). However, its effect on grain $\mathrm{Zn}$ concentrations varied for different cultivars (Table 3).

Foliar Zn spraying with or without sucrose did not affect yield traits of wheat (Tables 2, 4 and 5). Similar results were previously reported (Cakmak et al., 2010a; 2010b; Wang et al., 2012; Zhang et al., 2012b; Zhao et al., 2014). These results might be attributed to the relatively high $\mathrm{Zn}$ availability in the soils studied and thus the high plant $\mathrm{Zn}$ nutritional status. In agreement with others (Cakmak et al., 2010a; Wang et al., 2012; Zhang et al., 2012b), foliar $\mathrm{Zn}$ supply alone significantly increased grain $\mathrm{Zn}$ accumulation irrespective of wheat cultivars and environmental conditions in this study (Tables 3-5). Remarkably, a synergistic 'sucrose $+\mathrm{Zn}$ ' spraying increased grain Zn more than $\mathrm{Zn}$ alone. Clearly, the foliar spray of 'sucrose $+\mathrm{Zn}$ ' had achieved the grain $\mathrm{Zn}$ concentrations close to or more than the biofortification target value of $60 \mathrm{mg} \mathrm{kg}^{-1}$ according to the World Health Organization (WHO) report in 2006 (WHO, 2006). The relatively higher effectiveness of 'sucrose $+\mathrm{Zn}$ ' can be attributed to a longer drying time of the $\mathrm{Zn}$ solution and improved leaf cuticle penetration and/or translocation rates of $\mathrm{Zn}$ from the site of absorption to grains, as suggested by Zhao et al. (2014). Further studies are needed to identify whether these processes are all manipulated by sucrose and ascertain their relative contributions to increased grain $\mathrm{Zn}$ accumulation. 
In other studies, the effectiveness of foliar $\mathrm{Zn}$ application on the grain $\mathrm{Zn}$ concentration is related to the spray timing, location, rate and environmental conditions (Cakmak et al., 2010a; 2010b; Zhang et al., 2012b). Our study showed the grain Zn concentration of 'Liangxing 99' in 'sucrose $+\mathrm{Zn}$ ' under field conditions was $28.5 \%$ lower than in the pot experiment. In order to further enhance $\mathrm{Zn}$ absorption and translocation to grains to achieve the target value of $60 \mathrm{mg} \mathrm{kg}^{-1}$ in field, appropriately increasing spraying times and the $\mathrm{Zn} /$ sucrose concentration and/or spraying with other fertilizers (e.g. N) might be beneficial (Zhao et al., 2014), which deserves further study.

In this current study, the remarkable decrease in molar ratios of PA/Zn and $\mathrm{PA} \times \mathrm{Ca} / \mathrm{Zn}$ by foliar $\mathrm{Zn}$ supply with or without sucrose suggests the potentially increased grain $\mathrm{Zn}$ bioavailability (Table 5). The molar ratio of PA $\times \mathrm{Ca} /$ $\mathrm{Zn}$ below the critical ratio of 200 indicated a good Zn bioavailability (Ellis et al., 1987). The sucrose $+\mathrm{Zn}$ treatment led to a relatively higher $\mathrm{Zn}$ bioavailability than the Zn-only treatment. Especially, molar ratios of PA/Zn of 'Jinan 17 ', 'Jimai 20' and 'Jimai 22' were reduced by sucrose $+\mathrm{Zn}$ treatment to less than 15 , representing about $35 \% \mathrm{Zn}$ availability according to the WHO report on trace elements in human nutrition and health (WHO, 1996). Cultivars obviously differed in their molar ratios of PA/Zn and PA $\times \mathrm{Ca} / \mathrm{Zn}$. 'Jinan 17', as a high-quality strong gluten wheat cultivar, had a higher grain $\mathrm{Zn}$ bioavailability than other three wheat cultivars. Grain $\mathrm{Zn}$ bioavailability of the most commonly used high-yielding 'Jimai 22' in China was the lowest with molar ratios of PA/Zn and PA $\times \mathrm{Ca} / \mathrm{Zn}$ higher than the critical value of 15 and 200 , respectively.

\section{CONCLUSIONS}

In this study, reducing plant inner carbohydrate sources by spike shading and defoliation changed the source-sink relationship and decreased grain $\mathrm{Zn}$ accumulation. Enlarging grain size or sink by removing stunting spikes had no obvious effects on grain $\mathrm{Zn}$ concentration. Foliar $\mathrm{Zn}$ spray is an effective way for biofortification of wheat grains with Zn. A synergistic external foliar supply of carbohydrate (sucrose) and Zn source is more effective than Zn-only spray in increasing grain $\mathrm{Zn}$ concentration and bioavailability. Mechanisms in relation to external sucrose supply (with or without $\mathrm{Zn}$ ) influencing grain $\mathrm{Zn}$ accumulation need to be elucidated in the future.

\section{ACKNOWLEDGEMENTS}

This work was supported by the Promotive Research Fund for Excellent Young and Middle-aged Scientists of Shandong Province of China (BS2015NY006), the State Key Laboratory of Crop Biology (China) (2016KF05), the Young Scientist Research Foundation of Crop Research Institute of Shandong Academy of Agricultural Sciences of China (SAAS) (3201-09), and the SAAS Innovation Project (CXGC2016B04).

\section{REFERENCES}

Cakmak, I. 2008. Enrichment of cereal grains with zinc: Agronomic or genetic biofortification? Plant and Soil 302:1-17.

Cakmak, I., Kalayci, M., Kaya, Y., Torun, A.A., Aydin, N., Wang, Y., et al. 2010a. Biofortification and localization of zinc in wheat grain. Journal of Agricultural and Food Chemistry 58:9092-9102.

Cakmak, I., and Pfeiffer, W.H., and McClafferty, B. 2010b. Biofortification of durum wheat with zinc and iron. Cereal Chemistry 87:10-20.

Ellis, R., Kelsay, J.L., Reynolds, R.D., Morris, E.R., Moser, P.B., and Frazier, C.W. 1987. Phytate:zinc and phytate $\times$ calcium:zinc milli-molar ratios in self-selected diets of Americans, Asian Indians, and Nepalese. Journal of the American Dietetic Association 87:1043-1047.

Haug, W., and Lantzsch, H.J. 1983. Sensitive method for the rapid determination of phytate in cereals and cereal products. Journal of the Science of Food and Agriculture 34:1423-1426.

Kutman, U.B., Kutman, B.Y., Ceylan, Y., Ova, E.A., and Cakmak, I. 2012. Contributions of root uptake and remobilization to grain zinc accumulation in wheat depending on post-anthesis zinc availability and nitrogen nutrition. Plant and Soil 361:177-187.

Liu, N., Zhang, Y.H., Wang, B., Xue, Y.W., Yu, P., Zhang, Q., et al. 2014. Is grain zinc concentration in wheat limited by source? Australian Journal of Crop Science 8:1534-1541. 
Ma, Y.Z., MacKown, C.T., and van Sanford, D.A. 1996. Differential effects of partial spikelet removal and defoliation on kernel growth and assimilate partitioning among wheat cultivars. Field Crops Research 47:201-209.

Morris, E.R., and Ellis, R. 1982. Phytate, wheat bran, and bioavailability of dietary iron. ACS Symposium Series 203:121-141.

Pearson, J.N., Jenner, C.F., Rengel, Z., and Graham, R.D. 1996a. Differential transport of Zn, Mn and sucrose along the longitudinal axis of developing wheat grains. Physiologia Plantarum 97:332-338.

Pearson, J.N., Rengel, Z., Jenner, C.F., and Graham, R.D. 1996b. Manipulation of xylem transport affects Zn and Mn transport into developing wheat grains of cultured ears. Physiologia Plantarum 98:229-234.

Ryan, M.H., McInerney, J.K., Record, I.R., and Angus, J.F. 2008. Zinc bioavailability in wheat grain in relation to phosphorus fertiliser, crop sequence and mycorrhizal fungi. Journal of the Science of Food and Agriculture 88:1208-1216.

Sasaki, H., Edo, E., Uehara, N., Ishimaru, T., Kawamitsu, Y., Suganuma, S., et al. 2005. Effect of sucrose on activity of starch synthesis enzymes in rice ears in culture. Physiologia Plantarum 124:301-310.

Wang, Z., Fu, J., He, M., Tian, Q., and Cao, H. 1997. Effect of source/sink manipulation on net photosynthetic rate and photosynthate partitioning during grain filling in winter wheat. Biologia Plantarum 39:379-385.

Wang, J.W., Mao, H., Zhao, H.B., Huang, D.L., and Wang, Z.H. 2012. Different increases in maize and wheat grain zinc concentrations caused by soil and foliar applications of zinc in Loess Plateau, China. Field Crops Research 135:89-96.

Wang, Y.X., Specht, A., and Horst, W.J. 2011. Stable isotope labelling and zinc distribution in grains studied by laser ablation ICP-MS in an ear culture system reveals zinc transport barriers during grain filling in wheat. New Phytologist 189:428-437.

WHO. 1996. Trace elements in human nutrition and health. World Health Organization (WHO), Geneva, Switzerland. Available at http://www.who.int/nutrition/publications/micronutrients/9241561734/en/ (accessed July 2015).

WHO. 2006. Guidelines on food fortification with micronutrients. World Health Organization(WHO), Geneva, Switzerland. Available at http://www.who.int/nutrition/publications/micronutrients/9241594012/en/ (accessed December 2015).

Xue, Y.F., Zhang, W., Liu, D.Y., Yue, S.C., Cui, Z.L., Chen, X.P., et al. 2014. Effects of nitrogen management on root morphology and zinc translocation from root to shoot of winter wheat in the field. Field Crops Research 161:38-45.

Zhang, Y.Q., Sun, Y.X., Ye, Y.L., Rezaul, K.M., Xue, Y.F., Yan, P., et al. 2012b. Zinc biofortification of wheat through fertilizer applications in different locations of China. Field Crops Research 125:1-7.

Zhang, S.S., Yue, S.C., Yan, P., Qiu, M.L., Chen, X.P., and Cui, Z.L. 2013. Testing the suitability of the end-of-season stalk nitrate test for summer corn (Zea mays L.) production in China. Field Crops Research 154:153-157.

Zhang, Y.H., Zhang, Y.P., Liu, N., Su, D., Xue, Q.W., Stewart, B.A., et al. 2012a. Effect of source-sink manipulation on accumulation of micronutrients and protein in wheat grains. Journal of Plant Nutrition and Soil Science 175:622-629.

Zhao, A.Q., Tian, X.H., Cao, Y.X., Lu, X.C., and Liu, T. 2014. Comparison of soil and foliar zinc application for enhancing grain zinc content of wheat when grown on potentially zinc-deficient calcareous soils. Journal of the Science of Food and Agriculture 94:2016-2022. 